\title{
Isolation and molecular characterization of symbiotic fungus from Acromyrmex ambiguus and Acromyrmex heyeri ants of Rio Grande do Sul State, Brazil
}

\author{
Isolamento e caracterização molecular do fungo simbionte de formigas-cortadeiras \\ (Acromyrmex heyeri e Acromyrmex ambiguus) do Rio Grande do Sul, Brasil \\ Daniela Isabel Brayer Pereira ${ }^{\text {I }}$ Sônia de Avila Botton ${ }^{\text {II }}$ Maria Isabel de Azevedo ${ }^{\text {II }}$ \\ Danieli Urach Monteiro"I Carla Weiblen" Vanessa Schopt Machado ${ }^{\text {II }}$ \\ Michele Guimarães Donatti ${ }^{\text {II }}$ Alci Enimar Loeck ${ }^{\text {II }}$
}

\section{ABSTRACT}

Leaf-cutting ants of the genera Atta and Acromyrmex determine serious agricultural problems and live on symbiosis with Leucoagaricus gongylophorus. The aim of this study is to identify morphological and molecularly, as well as to verify the genotypic variability of the symbiotic fungus cultivated by $\boldsymbol{A}$. heyeri and $A$. ambiguus from three different regions of the state of Rio Grande do Sul, Brazil. Fungus gardens were collected and fragments of mycelia were grown in selective medium. Total DNA was extracted and amplification of the ITS region was performed by PCR using universal primers. After DNA sequencing, the chromatograms were assembled and phylogenetic analyzes were performed by the Neighbor-Joining method. A total of six isolates of $\boldsymbol{L}$. gongylophorus were obtained and their identities were confirmed by molecular analyses. Phylogenetic analysis of the ITS region showed a tree with two distinct groups regarding the fungus isolates from A. heiyeri and A. ambiguous. In this study, it was verified that $\boldsymbol{A}$. heyeri and $\boldsymbol{A}$. ambiguous, cultivate the same fungus. Additionally, the molecular marker used in this study showed variations in L. gongylophorus, evidencing two distinct branches in the phylogenetic tree, according to the ant species that cultivate $\boldsymbol{L}$. gongylophorus. However, other studies involving the inclusion of a great number of isolates of $\boldsymbol{L}$. gongylophorus, as well as the use of other molecular markers to validate the possible variations in the phylogenetic relationship of this symbiotic fungus are required.

Key words: Basidiomycete, Leucoagaricus gongylophorus, internal transcribed spacer.

\section{RESUMO}

Formigas-cortadeiras dos gêneros Atta e Acromyrmex causam elevados prejuizos à agricultura e são dependentes obrigatórias da simbiose com Leucoagaricus gongylophorus. $O$ objetivo deste estudo foi identificar morfologicamente e molecularmente, bem como verificar a variabilidade genotípica do fungo simbionte, cultivado por Acromyrmex heyeri e Acromyrmex ambiguus em três regiões do RS, Brasil. Jardins de fungo foram coletados do interior de formigueiros e fragmentos de micélio foram cultivados em meio de cultura seletivo. O DNA total foi extraído e a amplificação da região ITS foi realizada por PCR, utilizando primers universais. Após sequenciamento, os cromatogramas foram montados e as análises filogenéticas foram realizadas pelo método de NeighborJoining. Dos jardins de fungo, obtiveram-se seis isolados de $\boldsymbol{L}$. gongylophorus, confirmados por análise molecular. $A$ análise filogenética da região ITS mostrou uma árvore com dois grupos distintosem relação aos isolados do fungo oriundos de ninhos de $A$. heyeri e A. ambiguus. Neste estudo, evidenciou-se que as espécies de formigas $\boldsymbol{A}$. heyeri e A. ambiguus cultivam o mesmo fungo. Entretanto, o marcador molecular estudado evidenciou variações de L. gongylophorus que permitiram formar duas ramificações diferentes na árvore filogenética relacionada à espécie de formiga que o cultiva. Todavia, para validar as possíveis variações nas relações filogenéticas deste fungo simbionte, é necessária a inclusão de um maior número de isolados de L. gongylophorus, bem como o emprego de outros marcadores moleculares.

Palavras-chave: Basidiomicetos, Leucoagaricus gongylophorus, internal transcribed spacer.

\section{INTRODUCTION}

Leaf-cutting ants belong to the family Formicidae which are grouped in the Attine tribe

'Departamento de Microbiologia e Parasitologia, Instituto de Biologia, Universidade Federal de Pelotas (UFPel), 96010-900, Pelotas, RS, Brasil. E-mail: danielabrayer@gmail.com. Corresponding author.

IIDepartamento de Medicina Veterinária Preventiva, Centro de Ciências Rurais (CCR), Universidade Federal de Santa Maria (UFSM),

Santa Maria, RS, Brasil.

IIIDepartamento de Entomologia, Faculdade de Agronomia, UFPel, Pelotas, RS, Brasil. 
and included in the sub-family Myrmicinae. The Attine ants are found only in Neotropical regions and are distributed between southern South America and the southern United States (MEHDIABADI \& SCHULTZ, 2010). The genera Atta and Acromyrmex stands out due to the damage they cause, both in native plants and at cultivated plants, in which they cut fresh material that serves as a substrate for the cultivation of the symbiotic fungus inside their nests (CHAPELLA et al., 1994; MUELLER et al., 2001). All Attine ants (that includes about 256 described species in 15 genera) (SOSA-CALVO et al., 2013) are mandatory dependent on this symbiosis, which involves Lepiotaceaeous fungi (order Agaricales, Basidiomycota division) (CHAPELA et al., 1994). This fungus is considered of monophyletic origin, having co-evolved with the ants for 50 million years through vertical transmission (CHAPELA et al., 1994; MUELLER et al., 2001).

The symbiosis between ants and their fungus has been subject of many studies involving biochemical (BORBA et al., 2006; BACCI JR et al., 2013), metabolic and molecular aspects (SILVA-PINHATI et al., 2004).The results of this research demonstrate mostly that different species of leaf-cutting ants cultivate only Leucoagaricus gongylophorus as a single species of symbiotic fungus (SILVA-PINHATI et al., 2004; POULSEN $\&$ BOOMSMA, 2005). However, they could present two different strains (SILVA-PINHATI et al., 2004). Moreover, the behavioral characteristics of fungal growth cultivated for different ants species differ in different culture media (LOECK et al., 2004; BORBA et al., 2006), and the foraging habits of different species of leaf cutting ants suggest that the symbiotic fungus can present nutritional differences (BORBA et al., 2006).

In Rio Grande do Sul, the main species of leaf-cutting ants belong to the genus Acromyrmex, and plenty of the species to Acromyrmex heyeri and Acromyrmex ambiguus. The first uses monocotyledonous leaves, while the second uses dicotyledonous leaves for cultivation of their symbiotic fungus (LOECK \& GRUTZMACHER, 2001). Until now, molecular studies about the genetic diversity of these symbiotic fungus species of ants are not reported in the literature. The aim of this study is to identify morphological and molecularly, as well as to verify the genotypic variability of the symbiotic fungus cultivated by $\boldsymbol{A}$. heyeri and $\boldsymbol{A}$. ambiguus derived from three different regions of the state of Rio Grande do Sul, Brazil.

\section{MATERIAL AND METHOD}

The research was performed with the species $\boldsymbol{A}$. heyeri (narrow leaf cutter) and $\boldsymbol{A}$. ambiguus (cutter broadleaf) covering three regions of the state of Rio Grande do Sul: South region, in the city of Pelotas (Latitude: 31 46'19"S - Longitude: $52^{\circ} 20^{\prime} 33^{\prime \prime} \mathrm{W}$ ), campaign region in the city of Bage (Latitude: $31^{\circ} 19^{\prime} 53^{\prime \prime} \mathrm{S}$ - Longitude: 5406'25'W) and Central region, in the municipality of Santa Maria (Latitude: 2941'03"S-Longitude:5348'25”W). In each area, fungi garden of four nests of both ant species studied were collected. Fragments of mycelia were transferred to Petri plates containing Yeast Nitrogen Base Glucose Chloramphenicol culture media (YNBGC). The plates were incubated at $25^{\circ} \mathrm{C}$ for 30 days. Colonies suspected of having Leucoagaricus spp. were micromorphologic evaluated for their characteristics (presence of gongylidium) and picked into Petri dishes containing the same medium YNBGC without chloramphenicol (YNBG)

In order to obtain the total DNA, about $100 \mathrm{mg}$ of mycelium grown on YNBG agar was collected and frozen in liquid nitrogen over night $(\sim 16 \mathrm{~h})$. Total DNA was extracted according to the protocol described by MOLLER et al. (1992) and KLASSEN et al. (1996) with modifications (BOTTON et al., 2011), and the frozen isolates were macerated in a buffer lysis (beta 2-mercaptoethanol, $2 \% \mathrm{SDS}$ ), $10 \% \mathrm{CTAB}$ and $5 \mathrm{~N} \mathrm{NaCl}$, followed by phenol extraction and the total DNA was resuspended in sterile TE. The total DNA concentrations were determined using spectrophotometry. Amplification of the ITS region (intergenic transcribed spacer of ribosomal RNA), containing partial gene fragments of the spacer regions 1 and 2 of the internal transcribed and the region corresponding to the spacing between the 5.8S ribosomal DNA gene was performed by PCR using the universal primers ITS1 (5'-GTAGTCATATGCTTGTCTC-3') and ITS4 (5'CTTCCGTCAATTCCTTTAAG-3') (WHITE et al., 1990). All reactions were performed in a total volume of 50 $\mu$ l containing: $20 \mathrm{pmol}$ of each primer, 1.25 units Taq DNA polymerase (Invitrogen), 200nM deoxynucleotide (dNTP), 1X of the 10X enzyme buffer, $1.5 \mathrm{mM} \mathrm{MgCl} 2$, and 200ng of DNA samples. Amplifications were performed on thermocycler PTC-100 (Programmable Thermal Controller, MJ Research) under the following amplification conditions: $94^{\circ} \mathrm{C}$ for $5 \mathrm{~min}$, and 30 cycles of $94^{\circ} \mathrm{C}$ for $1 \mathrm{~min}, 55^{\circ} \mathrm{C}$ for $1 \mathrm{~min}$ and $72^{\circ} \mathrm{C}$ for $2 \mathrm{~min}$, ending with $72^{\circ} \mathrm{C}$ for $10 \mathrm{~min}$ and $4^{\circ} \mathrm{C}$ for $10 \mathrm{~min}$. The PCR products were separated on $1.2 \%$ agarose, stained 
with ethidium bromide and visualized under UV light gel. After verification, the amplified products were purified by the PureLink kit (Invitrogen) and the DNA fragments were sequenced in an automatic sequencer MegaBACE 500 using the DYEnamic ET kit (Amersham) employing the same primers used in the PCR reactions.

The DNA chromatograms sequences of the fungus were mounted and visualized using the GAP4 program from the Staden package (STADEN, 1996). Besides the gene sequences studied, four ITS gene sequences isolates from other Leucoagaricus species obtained from GenBank <http://www. ncbi.nlm.nih.gov/GenBank> to form the out group were used, including: Leucoagaricus barssii (GQ329062) Leucoagaricus hortensis (AF482843) and Tricholoma caligatum (AF319425). Another phylogenetic analysis was carried out using ITS sequences of $\boldsymbol{L}$. gongylophorus from different regions of Brazil, including: AY642809 and AY642810 (Acromyrmex subterraneus molestans); AY642813 (Acromyrmex disciger) and AY642814 (Acromyrmex rugosus), previously analyzed by SILVA-PINHATI et al. (2004). Multiple alignment of the data sets was performed by the Clustal W algorithm implemented in the MEGA5:03 (TAMURA et al., 2011) program. Phylogenetic analyzes were performed by analysis of neighbor-joining ( $\mathrm{NJ})$ method implemented in PAUP4.0b10, using 10,000 bootstrap.

\section{RESULTS}

From 48 collections of fungus gardens it was obtained six isolates with a mycelium growth of white cotton wool spots aspect. In the mycelium microscopic it was observed intumescences at the ends of the hyphae, consistent with gongylidium. Based on the macroscopic and microscopic characteristics obtained L. gongylophorus was preliminarily indentified. For each geographical area, as well as each species of ant it was obtained one isolated fungus.

In the molecular analysis, the DNA ITS region derived from the six isolates generated products of approximately $600 \mathrm{pb}$. The samples were amplified, sequenced and compared with the Basic Local Alignment Search Tool (BLAST), where it was possible to confirm the isolates as L. gongylophorus. The DNA sequences obtained from sequencing are available in GenBank (Table 1).

Phylogenetic analysis of the $\boldsymbol{L}$. gongylophorus ITS region isolates obtained in this study showed a tree with two distinct groups (Figure 1). The results showed that the isolates of $\boldsymbol{L}$. gongylophorus coming from nests of $\boldsymbol{A}$. heiyeri and A. ambiguus collected in three different regions of Rio Grande do Sul, were grouped according to the ant species independently of the geographic region (Figure 1 and 2). Thus, L. gongylophorus cultivated by $\boldsymbol{A}$. heyeri clustered forming the AH group, while isolates of $\boldsymbol{L}$. gongylophorus cultivated by A. ambiguus constituted the AA group (Figure 1). When the phylogenetic analysis was performed, which included other L. gongylophorus samples from different regions of Brazil it was observed that isolates from A. ambiguus form a distinct group, whereas isolates derived from $\boldsymbol{L}$. gongylophorus from $\boldsymbol{A}$. heyeri were grouped with the remaining Brazilian isolates analyzed (Figure 2).

\section{DISCUSSION}

In this study, which includes Santa Maria, Bage and Pelotas municipalities (RS/Brazil), it was possible to prove that leaf-cutting ants $A$. heyeri and $A$. ambiguus grown $L$. gongylophorus in their gardens. Until now, only BORBA et al. (2006) had reported the isolation of this symbiotic fungi in the leaf-

Table1 - Isolates of Leucoagaricus gongylophorus derived from Acromyrmex heyeri and Acromyrmex ambiguus from three regions of Rio Grande do Sul, Brazil.

\begin{tabular}{|c|c|c|c|}
\hline Isolate & Ant source & City/Region & Genbank Access* \\
\hline L. gongylophorus A.h -SM & A. heyeri & Santa Maria/Central & KJ531211 \\
\hline L. gongylophorusA.h - P & A. heyeri & Pelotas/South & KJ531209 \\
\hline L. gongylophorus A.h - B & A. heyeri & Bagé/Campanha & KJ531208 \\
\hline L. gongylophorus A.a - SM & A. ambiguus & Santa Maria/Central & KJ176716 \\
\hline L. gongylophorus A. a - P & A. ambiguus & Pelotas/South & KJ531207 \\
\hline L. gongylophorusA.a - B & A. ambiguus & Bagé/Campanha & KJ531210 \\
\hline
\end{tabular}

*Based on ITS region. 


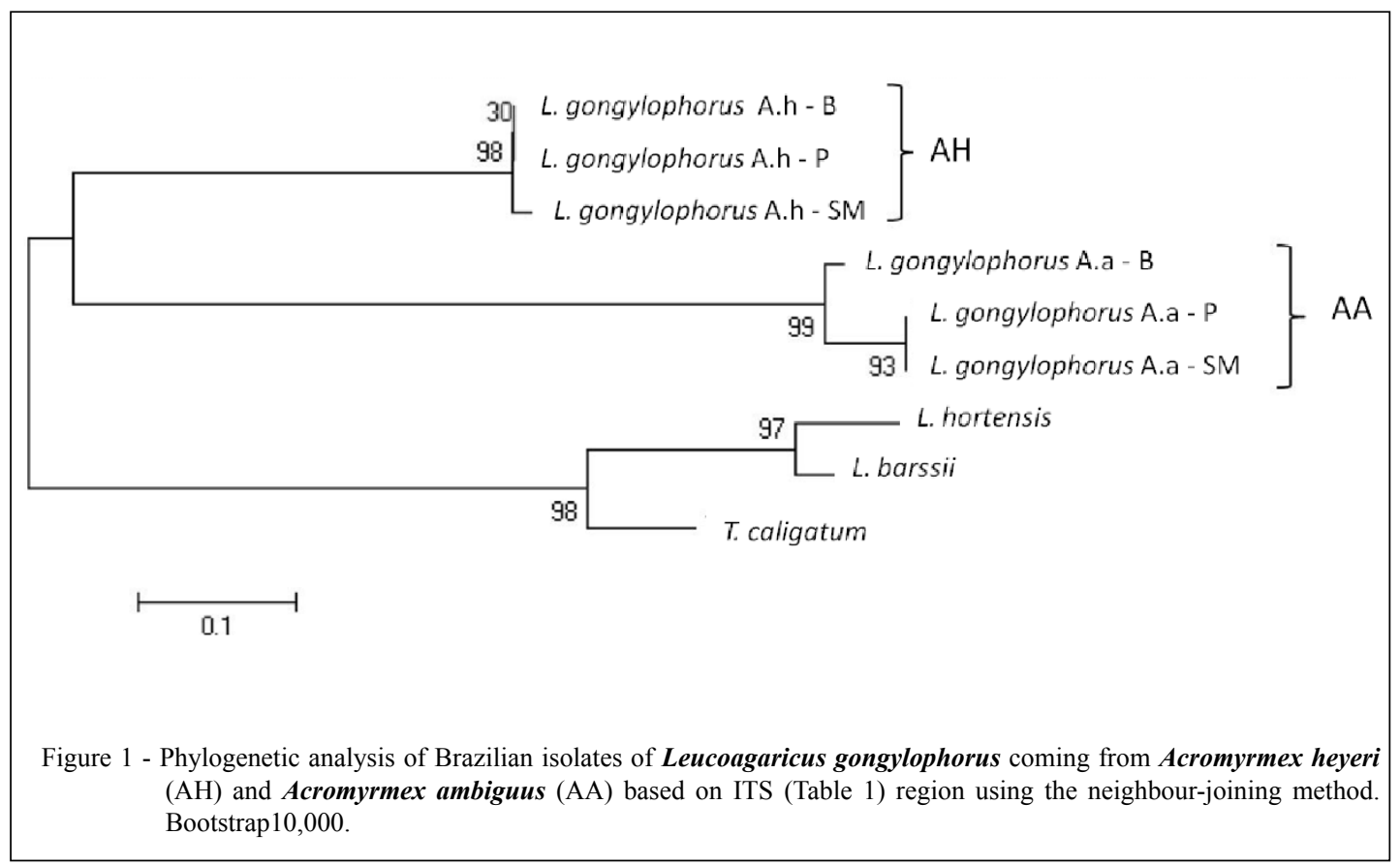

cutting ants A. heyeri, A. ambiguus, Acromyrmex crassipinus and Acromyrmex lundi in the municipal district of Capão do Leão (Brazil/RS), without, however, including the molecular identification of the fungus. In another study, comprising the southern and northern regions of Brazil, SILVA-PINHATI et al. (2004) performed the cultivation and molecular characterization of $\boldsymbol{L}$. gongylophorus in the Attine ant tribe including Atta and Acromyrmex species. However, these authors did not include in their study the $\boldsymbol{A}$. heyeri and $A$. ambiguus.

Molecular analysis of the ITS region showed that although the species A. ambiguus and A. heyeri cultivate the same fungus, fungal intra species differences were observed, since it showed the formation of two distinct groups shown in the phylogenetic tree (Figure 1). Furthermore, it was observed that $\boldsymbol{L}$. gongylophorus from $\boldsymbol{A}$. heyeri showed greater genetic similarity with other isolates from different regions of Brazil (SILVA-PINHATI et al., 2004) that isolates from $\boldsymbol{A}$. ambiguus, which formed a distinct group (Figure 2). These differences may be associated with a co-evolution of the fungus with ants which forage with different leaf types (mono and dicotyledoneous). In addition to the variation in the nutritional constitution of sheets, there are also differences in the substrate preparation by the ants. $A$. heyeri cultivate the fungus on fragments of entire leaves, while $A$. ambiguus breaks the leaves into tiny pieces. In this sense, studies have shown that $\boldsymbol{L}$. gongylophorus come from different genera and species of leaf-cutting ants exhibit different physiological behaviors with respect to the culture medium, $\mathrm{pH}$ and temperature (BORBA et al., 2006; BORBA et al., 2007). In addition, POULSEN \& BOOMSNA (2005) showed that agricultural monoculture developed by leaf-cutting ants is actively imposed by its symbiotic fungus. Previously, SILVA-PINHATI et al. (2004) evaluated the DNA and the intergenic region of $\boldsymbol{L}$. gongylophorus ants coming from the Attine tribe in southeastern and northern Brazil and observed a high similarity of the cultured symbiotic fungus, suggesting that leaf-cutting ants cultivate the same fungus species in a wide geographic region of South America. In the present study, the results did not differ from these authors in relation to the kind of symbiotic fungi cultivated by leaf-cutting ants. Moreover, it showed the formation of two distinct groups (AH and AA) determined by the ant species independently of the geographical region studied. Agreeing with the results, other studies also claimed that different strains of leaf-cutting ants can cultivate in their nests the same symbiotic fungus (MUELLER, 2001; MIKHEYEV et al., 2007). On the other hand, DOHERTY et al. (2003) using the RAPD (Random amplified polymorphic DNA) observed genetic variability in isolates originated from symbiotic fungus of Atta cephalotes from Panama and Trinidad.

Although the ITS region is widely used in phylogenetic studies of several fungi, the evolution 


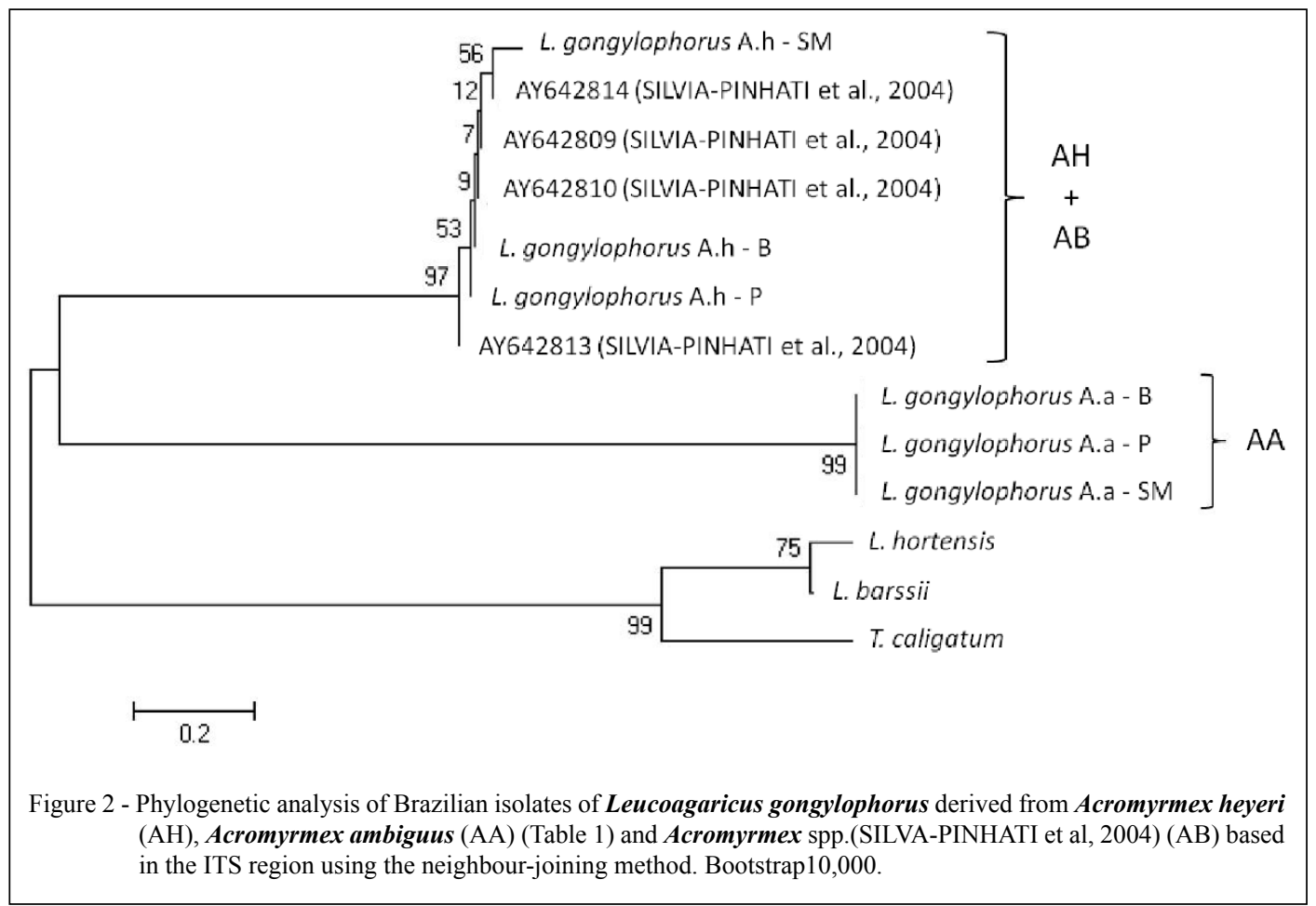

of a gene may not represent the evolution of the whole genome (SHEN, 2001). The genes encoding the structural and metabolic proteins such as cytochromec oxidase subunit II (COXII) are being increasingly investigated; since this gene mutations were accumulate throughout evolution, which is useful to determine phylogenetic relationships (MARTIN, 2000).

Whereas L. gongylophorus presents metabolic and nutritional changes depending on the kind of the cultivated leaf-cutting ant (BORBA et al., 2006), it can be suggested that future studies evaluating other more sensitive molecular markers such as COXII, are necessary to evaluate, validate and determine the phylogenetic relationships among isolates of $\boldsymbol{L}$. gongylophorus from different strains of leaf-cutting ants.

\section{CONCLUSION}

Based on the results of this study, it was suggested that both species $\boldsymbol{A}$. heyeri and $\boldsymbol{A}$. ambiguus, from Rio Grande do Sul, Brazil, cultivated the same fungus. However, the molecular marker studied showed variations of $\boldsymbol{L}$. gongylophorus evidencing two distinct branches in the phylogenetic tree related to the ant species that cultivates the fungus. On the other hand, it is required the inclusion of a large number of $\boldsymbol{L}$. gongylophorus isolates, as well as the use of other molecular markers to validate the possible variations in the phylogenetic relationship of this symbiotic fungus.

\section{ACKNOWLEDGEMENTS}

We thank the Conselho Nacional de Desenvolvimento Científico e Tecnológico (CNPq), grant number: 556570/2010-3.

\section{REFERENCES}

BACCI JR., M. et al. A metabolic pathway assembled by enzyme selection may support herbivory of leaf-cutter ants on plant starch. Journal of Insect Physiology, v.59, p.525-531, 2013. Available from: $<$ http://www.ncbi.nlm.nih.gov/pubmed/23500892>. Accessed: Jan. 31, 2014. doi: 10.1016/j.jinsphys.2013.02.007.

BORBA, R.S. et al. Crescimento do fungo simbionte de formigas cortadeiras do gênero Acromyrmex em meios de cultura com diferentes extratos. Ciência Rural, v.36, p.725-730, 2006. Available from: <http://www.scielo.br/pdf/cr/v36n3/a02v36n3. pdf $>$. Accessed: Dec. 10, 2013.

BORBA, R.S. et al. Polimorfismo do fungo simbionte de formigas cortadeiras submetido à luz ultravioleta. Ciência Rural, v.37, p.1221-1226, 2007. Available from: <http://www.scielo.br/pdf/cr/ v37n5/a01v37n5.pdf>. Accessed: Oct. 15, 2014.

BOTTON, S.A. et al. Identification of Pythium insidiosum by Nested PCR in cutaneous lesions of Brazilian horses and rabbits. Current Microbiology, v.62, p.1225-1229, 2011. Available from: 
<http://www.ncbi.nlm.nih.gov/pubmed/21188592>. Accessed: Dec. 15, 2013. doi: $10.1007 /$ s00284-010-9781-4.

CHAPELA, I.H. et al. Evolutionary history of the symbiosis between fungus-growing ants and their fungus. Science, v.266, p.1691-1694, 1994. Available from: <http://entomology.si.edu/ staffpages/schultz\%20et\%20al/Pubs/1994_Science266-EvolHist. pdf>. Accessed: Nov. 29, 2013.

DOHERTY, K.R. et al. Random amplified polymorphic DNA markers reveal genetic variation in the symbiotic fungus of leafcutting ants. Mycologia, v.95, p.19-23, 2003. Available from: $<$ http://www.ncbi.nlm.nih.gov/pubmed/21156584>. Accessed: Nov. 30, 2013.

KLASSEN, G.R. et al. 5S ribosomal RNA gene spacer as species specific probes for eight species of Pythium. Phytopathology, v.86, p.581-587, 1996. Available from: <https://www.apsnet.org/ publications/phytopathology/backissues/Documents/1996Articles/ Phyto86n06_581.pdf $>$. Accessed: Jan. 30, 2014.

LOECK, A.E. et al. Growth of symbiont fungi of some higher Attine ants in mineral medium crescimento do fungo simbionte de alguns Attine superiores em meio mineral. Ciência Rural, v.34, p.79, 2004. Available from: <http://www.scielo.br/pdf/cr/v34n1/ a12v34n1.pdf $>$. Accessed: Dec. 15, 2013.

LOECK, A.E., GRÜTZMACHER, D.D. Ocorrência de formigas cortadeiras nas principais regiões agropecuárias do Estado do Rio Grande do Sul. Pelotas: UFPEL, 2001. 1v.

MARTIN, F.N. Phylogenetic relationships among some Pythium species inferred from sequence analysis of the mitochondrially encoded cytochrome oxidase II gene. Mycologia, v.92, p.711-727, 2000. Available from: <http://www.jstor.org/stable/3761428>. Accessed: Jan. 29, 2014. doi: 10.2307/3761428.

MEHDIABADI, N.J.; SCHULTZ, T.R. Natural history and phylogeny of the fungus-farming ants (Hymenoptera: Formicidae: Myrmicinae: Attini). Myrmecological News, v.13, p.37-55, 2010. Available from: $<$ http://myrmecologicalnews.org/cms/index.php?option $=$ com_co ntent\&view=category\&id=399:myrmecol-news-13-37-55-onlineearlier\&Itemid $=64 \&$ layout $=$ default $>$. Accessed: Nov. 09, 2013.

MIKHEYEV, A.S. et al. Population genetic signatures of diffuse co-evolution between leaf-cutting ants and their cultivar fungi. Molecular Ecology, v.16, p.209-216, 2007. Available from: $<$ http://www.ncbi.nlm.nih.gov/pubmed/17181732>. Accessed: Dec. 08, 2013.doi: 10.1111/j.1365-294X.2006.03134.x.

MOLLER, E.M. et al. A simple and efficient protocol for isolation of high molecular weight DNA from filamentous fungi, fruit bodies, and infected plant tissues. Nucleic Acids Research, v.20, p.6115-6116, 1992. Available from: <http://www.ncbi.nlm.nih. gov/pmc/articles/PMC334490/>. Accessed: Jan. 30, 2013.

MUELLER, U.G. et al. The origin of the Attine ant-fungus mutualism. Quarterly Review of Biology, v.76, p.169197, 2001. Available from: <http://www.ncbi.nlm.nih. gov/pubmed/11409051>. Accessed: Jan. 31, 2014. doi: PMID:11409051

POULSEN, M.; BOOMSMA, J.J. Mutualistic fungi control crop diversity in fungus-growing ants. Science, v.4. p.741744, 2005. Available from: <http://www.ncbi.nlm.nih.gov/ pubmed/15692054>. Accessed: Nov. 17, 2013. doi: 10.1126/ science. 1106688 .

SHEN, Q.S. Molecular phylogenetic analysis of Grifolafrondosa (Maitake) and related species and the influence of selected nutrient supplements on mushroom yield. 2001. 141f. Doctoral dissertation - The Pennsylvania State, University Graduate School.

SILVA-PINHATI, A.C.O. et al. Low variation in ribosomal DNA and internal transcribed spacers of the symbiotic fungi of leafcutting ants (Attini: Formicidae). Brazilian Journal of Medical and Biological Research, v.37, p.1463-1472, 2004. Available from: $<$ http://www.scielo.br/scielo.php?script $=$ sci arttext\&pid=S0100879X2004001000004>. Accessed: Nov. 27, 2013. doi:10.1590/ S0100-879X2004001000004.

SOSA-CALVO, J. et al. Cyatta abscondita: taxonomy, evolution, and natural history of a new fungus-farming ant genus from Brazil. PLoS ONE, v.8, p.e80498, 2013. Available from: <http:// www.plosone.org/article/info\%3Adoi\%2F10.1371\%2Fjournal. pone.0080498>. Accessed: Oct. 05, 2014. doi: 10.1371/journal. pone. 0080498 .

STADEN, R. The Staden sequence analysis package. Molecular Biotechnology, v.5, p.233-241, 1996. Available from: <http://link. springer.com/article/10.1007/BF02900361\#page-1>. Accessed: Dec. 03, 2013. doi: 10.1007/BF02900361.

TAMURA, K. et al. MEGA5: molecular evolutionary genetics analysis using maximum likelihood, evolutionary distance, and maximum parsimony methods. Molecular Biology and Evolution, v.28, p.2731-2739, 2011. Available from: <http://mbe. oxfordjournals.org/content/28/10/2731.full.pdf + html $>$. Accessed: Dec. 03 2013. doi: 10.1093/molbev/msr121.

WHITE, T. et al. Amplification and direct sequencing of fungal ribosomal RNA genes for phylogenetics. In: INNIS, M. PCR protocols: a guide to methods and applications. New York: Academic, 1990. p.315-322. 


\section{ERRATUM}

Article "Isolation and molecular characterization of symbiotic fungus from Acromyrmex ambiguus and Acromyrmex heyeri ants of Rio Grande do Sul State, Brazil" published in volume 45 number 7 July 2015 in the journal Ciência Rural pages 1256-1261 on the affiliation of the authors where we read:

"Vanessa Schopt Machado"
should read:
"Vanessa Schopf Machado"

For the correction version please use:

http://www.scielo.br/pdf/cr/v45n7/1678-4596-cr-0103_8478cr20141064.pdf 